\title{
Microbiological Quality of Raw Cow's Milk In and Around Bahir Dar City, Ethiopia
}

\author{
Birhanu Yeserah $^{1 *} \quad$ Asaminew Tassew ${ }^{2} \quad$ Hailu Mazengia $^{2}$ \\ 1.Debre Tabor University, College of Agriculture and Environmental Sciences \\ 2.Bahir Dar University, College of Agriculture and Environmental Sciences
}

\begin{abstract}
The study was conducted to investigate microbiological quality of raw cow's milk in and around Bair Dar city. The data were collected through laboratory analysis of raw cow's milk. For this purpose 80 milk samples were collected for platform tests and to analyze the microbiological quality of milk. The laboratory analysis was done in Bahir Dar University school of Food and Biochemical Technology laboratory from December 2017 to January 2018. Based on the result of platform tests on milk quality, out of the total collected and tested milk samples $13.8 \%$ were positive with clot on boiling test and $22.5 \%$ of samples had positive result with alcohol test which indicates the alcohol test is more sensitive than the clot-on-boiling test. There was a significance difference $(p<0.01)$ in colt on boiling test and $(\mathrm{p}<0.05)$ in alcohol test amongst production systems. The highest $(0.235 \pm 0.008)$ titratable acidity of raw cow's milk was observed in rural areas. The overall mean coliform count, standard plate count, yeast and mold count and staphylococcus aureus count of raw milk produced in the area were $4.95 \pm 0.18$ $\log _{10} \mathrm{cfu} / \mathrm{ml}, 7.11 \pm 0.13 \log _{10} \mathrm{cfu} / \mathrm{ml}, 4.12 \pm 0.14 \log _{10} \mathrm{cfu} / \mathrm{m}$ and $3.36 \pm 0.11 \log _{10} \mathrm{cfu} / \mathrm{ml}$, respectively. The milk samples collected from rural area, cooperatives, unwashed udder, gourd container and unwashed hands revealed poor microbiological quality and are far below milk quality standards. Generally, the raw milk in the area was contaminated with various microorganisms. Therefore, stainless steel milk handling utensils, cooling system, health package and an educational program targeted at behavioral changes on water and milk hygiene are highly warranted.
\end{abstract}

Keywords: Milk handling practice, hygiene, microbial count

DOI: $10.7176 / \mathrm{FSQM} / 88-01$

Publication date:July $31^{\text {st }} 2019$

\section{Introduction}

Microbial load is a major factor in determining milk quality [1]. It indicates the hygienic level exercised during milking, cleanliness of the milk utensils, condition of storage, manner of transport as well as the cleanliness of the udder of the individual animals. Presence of bacteria in raw milk reduces the keeping quality of milk [2]. Since, the handling practice and production system is traditional, the cow's milk in Ethiopia is mostly contaminated with external sources which are bacteria and categorized as poor quality, mainly due to less attention for hygiene [3].

In fact, few farmers attempted to minimize sources of contamination during milking; however, there are no enough resources to do this effectively [4].

On the other hand the consumption of raw milk and its derivatives is common in Ethiopia, which is not safe from consumer health point of view as it may lead to the transmission of various diseases. Any improvement in the quality of milk could contribute to the insurance of public health safety while at the same time having positive economic consequences [5]. Provision of milk and milk products of good hygienic quality is desirable from both milk spoilage loss and public health point of view. This is one reason why milk testing and quality control include hygiene as well as microbial qualities are required in addition to platform tests. Consumers all over the world are increasingly concerned about the safety of their food in general and milk and milk products in particular.

So, quality should not be ignored at all stages of the dairy production process from producer to consumer. The microbial quality of raw milk is important for the product shelf-life, flavor and product yield, it is important for milk producer and cooperative should strive to obtain the highest quality raw milk possible from their own farm as well as their suppliers [6]. Most of the previous research works in Ethiopia were focused on the production and marketing system of milk and its product, nevertheless the quality aspects among different production systems are not well-investigated.

Putting a functional quality control system in place is an important tool to bring an improvement in the dairy sector and to sustain public health condition. However, the information on handling practice and microbiological quality of raw cow's milk in different dairy production systems and dairy cooperatives in and around Bahir Dar city is generally scantly and nil. Such information is critically important for designing appropriate hygienic milk handling practice, quality control measures and for further research development. In view of the above, the present study was conducted to analyze the microbiological quality of raw cow's milk collected from producers and cooperatives and to compare its quality against some of the national and international standards. 


\section{Materials and methods}

\subsection{Description of the study areas}

The study was conducted in and around Bahir Dar city which is the capital city of Amhara National Regional State. It's located at about $565 \mathrm{~km}$ away from Addis Ababa. The region covers a total area of 152,600 $\mathrm{km}^{2}$. The Region has 10.6 million cattle, 5.7 million sheep, 4 million goats, 2.1 million equines and 17,400 camels managed under extensive management system. Bahir Dar City is located at $11^{\circ} 35^{\prime} 37.10^{\prime \prime} \mathrm{N}$ latitude, $37^{\circ} 23^{\prime} 26.77^{\prime \prime}$ Longitude E on the South of Lake Tana where Blue Nile River starts. The elevation reported for the City is about $1801 \mathrm{~m}$.a.s.1. The area receives an average annual rainfall ranging between $850 \mathrm{~mm}$ to $1250 \mathrm{~mm}$ with the minimum and maximum average daily temperatures of $10^{\circ} \mathrm{c}$ and $32^{\circ} \mathrm{c}$, respectively [7].

\subsection{Milk sample collection and Sampling techniques}

Laboratory based investigation was used to determine quality of raw cow's milk. A total of 80 raw milk samples ( 75 from producers and 5 from cooperatives) each measuring $250 \mathrm{ml}$ volume [8], were randomly collected from milk storage containers of producers and cooperatives immediately after milking and collection, respectively. All (Bahir Dar, Tisabay, Tiret, Yegoma huletu and Abay Zuria) dairy cooperatives found in the study area were considered for raw milk sampling. Samples of milk were taken in the morning from each household once over a period of two months (December, 2017 and January, 2018) which may represent most of the dry seasons/months/ in a year. Milk samples collected from producers in each production system was compared each other to know the quality difference. Hygiene of cow's udder and milker's, types of milking container and sources of milk were also considered as factors for microbial counts.

During sample collection, the milk was mixed and transferred into sterile screw-capped sampling bottles (250 $\mathrm{ml}$ capacities) and placed in ice box as per the recommendations of IDF 50 ISO/DIS 707 [8]. Then it was securely capped, labeled with permanent markers and kept in an ice box filled with ice packs and transported as immediately as possible to Bahir Dar University school of Food and Biochemical Technology within the ice box for milk quality analysis within 20 minutes and then stored in refrigerator at $4^{\circ} \mathrm{C}$ before being analyzed within $24 \mathrm{hr}$ of sampling.

\subsection{Platform tests}

2.3.1. Clot-on-boiling test: In order to check the freshness of raw cow's milk, five ml of milk was placed in a test tube and then it was placed in a boiling water bath for five minutes. After that, the test tube was carefully removed from the water bath and examined for the presence of floccules [9]. If it had a coagulation or floccules recorded as a positive sample.

2.3.2. Alcohol test: The alcohol test was used on fresh milk to indicate whether it will coagulate on thermal processing. It is based on tendency of milk protein to get unstable as a result of disturbance in the mineral balance of milk. Equal quantity (five $\mathrm{ml}$ of milk and five $\mathrm{ml}$ of $68 \%$ alcohol (ethanol) was mixed and placed in a test tube. Then the test tube was inverted several times with the thumb held tightly over the open end of the tube. The tubes were shaken to mix and any clot formation was noted [10]. If the tested milk is of good quality, there was no coagulation, clotting or precipitation. Presence of flakes or clots indicates poor quality milk.

2.3.3. Titratable acidity test: Nine $\mathrm{ml}$ of milk was pipetted into a beaker and then $3-5$ drops $(1 \mathrm{ml})$ of 1 percent phenolphthalein indicator was added into the milk. Then the sample was titrated with $0.1 \mathrm{~N} \mathrm{NaOH}$ solution until definite pink color appears and the volume of sodium hydroxide used in the titration was recorded [11]. The following formula was used to calculate the lactic acid percentage [12].

$$
\text { Titratable acidity }(\%)=\frac{\mathrm{N} / 10 \mathrm{NaOH}(\mathrm{ml}) \times 0.009}{\mathrm{ml} \text { of sample }} \times 100
$$

The microbial analysis includes the determination of colony-forming units of coliform count, standard plate count, Staphylococcus aureus count and yeast and mold count which were determined in food microbiology laboratory. In addition the platform tests like titratable acidity, alcohol test and clot-on-boiling test were analyzed in food chemistry laboratory. After counting and recording bacterial colonies in each petri-dish the number of bacteria in milliliter was calculated by the following formula given by APHA [13].

$$
N=\frac{\sum C}{[(1 \times n 1)+(0.1 \times n 2)] \mathrm{d}}
$$

Where: $\mathrm{N}=$ Number of colonies per ml of milk $\Sigma \mathrm{C}=$ Sum of all colonies on all plates counted $\mathrm{n} 1=$ Number of plates in first dilution counted

$\mathrm{n} 2=$ Number of plates in second dilution counted $\mathrm{d}=$ Dilution from which the first counts was obtained. 


\subsection{Microbial counts}

2.4.1. Coliform count: $\mathrm{The} \mathrm{CC}$ is a test that estimates the number of bacteria that originate from manure or a contaminated environment. After mixing, the sample was serially diluted up to $1: 10^{-5}$ by transferring $1 \mathrm{ml}$ of the sample into $9 \mathrm{ml}$ of $0.1 \%$ peptone water for initial dilution and by transferring $1 \mathrm{ml}$ of the previous dilution into 9 $\mathrm{ml}$ of peptone water and the duplicate sample $(1 \mathrm{ml})$ were poured using 15-20 ml violet read bile agar solution (VRBA) (Figure 1). After complete solidification of the medium, cover the surface with a layer of the same medium. Then incubated at $37^{\circ} \mathrm{C}$ for 24 hours and the plates with $15-150$ colonies were selected and count only the typical coliforms colonies on the VRBA medium: red-purple, $0.5 \mathrm{~mm}$ or greater in diameter, surrounded by a reddish halo [14].

2.4.2. Standard plate count procedures: One measure of milk quality is the bacteria content of the raw milk. This is often termed the raw count or the standard plate count. Appropriate serial dilutions were selected that has given the expected total number of colonies on a plate. The standard plate count agar (PCA) was boiled, sterilized and then cooled to $45^{\circ} \mathrm{C}$ before pouring. One $\mathrm{ml}$ of milk sample was added into sterile test tube containing $9 \mathrm{ml}$ peptone water. After thoroughly mixing, the sample was serially diluted up to $10^{-7}$ and mixed thoroughly. Then one $\mathrm{ml}$ of the sample from appropriate decimal dilution was placed on a petri-dish and then plate count agar medium (10-15 ml) was poured onto the petri-dish. The plated sample was allowed to solidify and finally incubated at $37^{\circ} \mathrm{C}$ for 48 hours. Colony counts were made by using colony counter [15].

2.4.3. Yeast and mold count: Samples of milk were serially diluted up to $10^{-4}$ in peptone water and volumes of 0.1 milliliter of appropriate dilutions were plated in duplicate. A spread plate technique was employed using Dichloran Rose Bengal Chloramphenicol (DRBC). The inoculum $(0.1 \mathrm{ml})$ was spread with glass spreaders. The dried plates were then incubated at $25^{\circ} \mathrm{C}$ for 3 to 5 days. Colonies with filamentous, cotton-like or pulverulent (i.e. powdery) appearance were counted as yeasts and molds [14].

2.4.4. Staphylococcus aureus count procedures: From $1 \mathrm{ml}$ of each sample of raw milk, series of dilutions were prepared $\left(10^{-1}\right.$ to $\left.10^{-4}\right)$ of raw milk using a diluting $9 \mathrm{ml}$ of peptone solution at $0.1 \%$. Sterile pipettes were used to place $0.1 \mathrm{ml}$ aliquots from each dilution in to properly labeled mannitol salt agar (MSA) plates. The plates were spread and incubated (inverted) at $37^{\circ}$ for $48 \mathrm{hrs}$, typical staphylococcus aureus colonies appeared as golden yellow, smooth, circular, convex and moist were count [16].

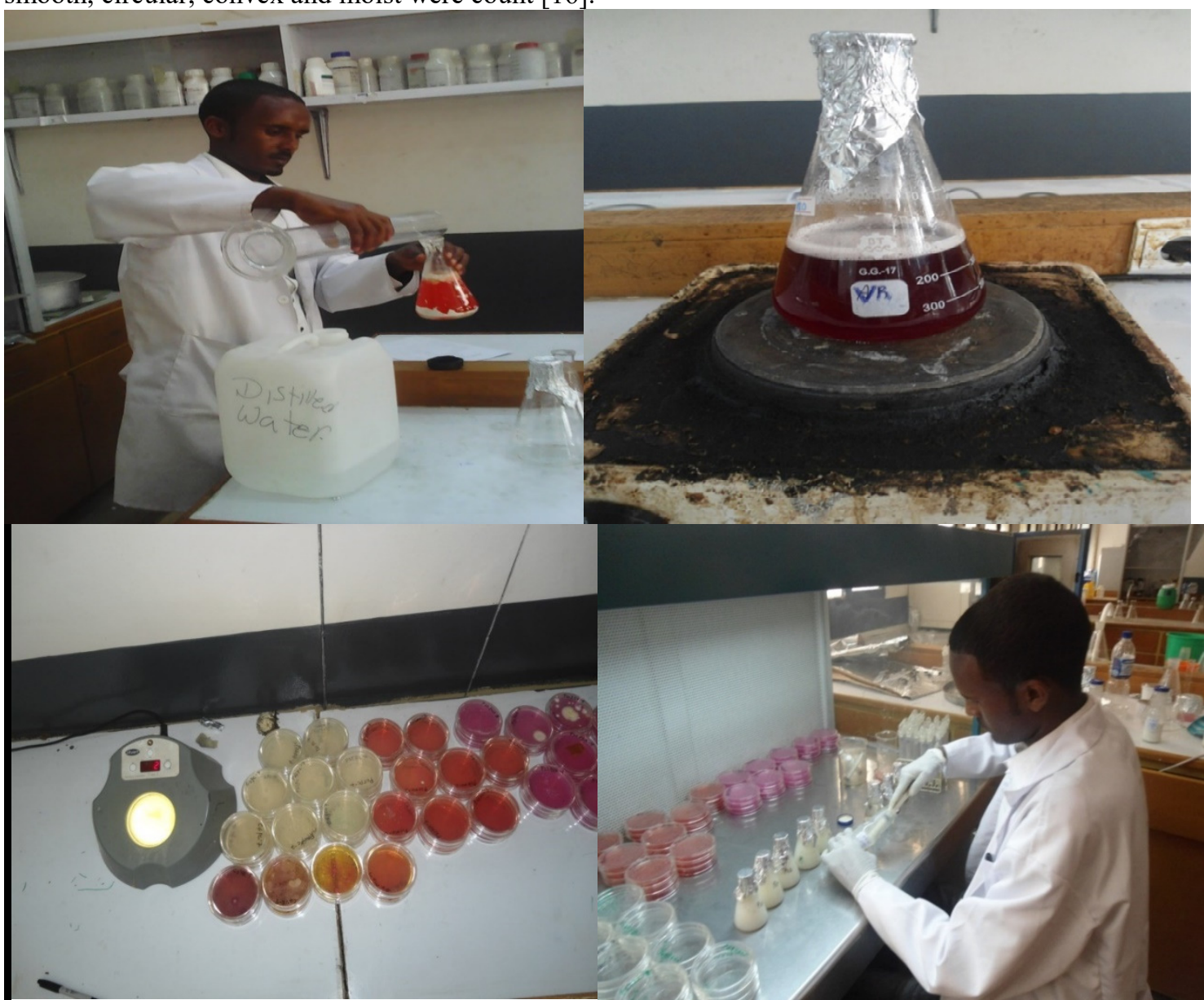

Figure1. Microbiological work in order to identify microbes found in raw cow's milk 


\subsection{Methods of data management and statistical analysis}

The data were entered in to Microsoft excel spread sheet. Data from microbial counts was first transformed to logarithmic values $\left(\log _{10}\right)$ to achieve parametric statistical tests. Then, data on the transformed microbial count values were analyzed using General Linear Model (GLM) procedure of (SAS, version 9.0). Mean separation was carried out using the Least Significant Difference (LSD) technique when analysis of variance shows significant differences between means. For all analysis, $95 \% \mathrm{CI}$ and $\mathrm{P}$-value $\leq 0.05$ were set for statistical significance of an estimate.

The following linear models have been used during analysis of coliform count of raw cow's milk.

$$
\text { Yijchs }=\mu+a i+b j+u c+m h+L s+\text { eijchs }
$$

Where $Y_{\mathrm{ijchs}}=$ Coliform count of raw cow's milk

$\mu=$ the overall mean

$a_{i}=$ The effect of $i^{\text {th }}$ production systems ( $i=$ urban, peri-urban, rural)

$b_{j}=$ The effect of $j^{\text {th }}$ source of milk ( $j=$ individual dairy producers, cooperative)

$\mathrm{u}_{\mathrm{c}}=$ The effect of $\mathrm{c}^{\text {th }}$ hygiene of cows udder ( $\mathrm{c}=$ washed udder, unwashed udder $)$

$\mathrm{m}_{\mathrm{h}}=$ The effect of $\mathrm{h}^{\text {th }}$ milking container ( $\mathrm{h}=$ gourd, plastic)

$\mathrm{L}_{\mathrm{s}}=$ The effect of $\mathrm{s}^{\text {th }}$ milker hygiene (washed hand, unwashed hand)

$\mathrm{e}_{\mathrm{ijchs}}=$ Random error

\section{Results and Discussions}

\subsection{Platform quality tests of raw cow's milk}

Out of the total collected and tested milk samples $13.8 \%$ and $22.5 \%$ of samples were positive with clot on boiling and alcohol tests, respectively (Table 1). The highest proportion of positive results by clot on boiling and alcohol tests was observed in rural production system. There was a statistically significance difference $(\mathrm{p}<0.01)$ in colt on boiling test and $(\mathrm{p}<0.05)$ in alcohol test amongst production systems. These observations support the view that, the alcohol test is more sensitive than the clot-on-boiling test as reported by O'Connor [9].

This result is smaller than the findings of [17] who reported 51 and $23 \%$ of the milk samples tested are likely to clot by the alcohol test and clot on boiling test, respectively in Bahirdar Zuria and Mecha district. On the other hand, only $21 \%$ of the milk samples tested in Bila Sayo and Guto Wayu of East Wollega were likely to clot on boiling [18].

The percentage of lactic acid present in milk at any time is a rough indicator of the age of the milk and the manner in which it has been handled [19]. The least square mean titratable acidity of raw cow's milk collected from rural areas was $0.235 \pm 0.0088 \%$ which was higher followed by cooperatives $(0.199 \pm 0.0231 \%)$ whereas relatively lower titratable acidity of raw milk was found in urban $(0.195 \pm 0.017)$ and peri-urban areas $(0.198 \pm 0.009)$ (Table1). Popescu and Angel reported that high quality milk has to have less than 0.14 percent acidity [20]. Therefore the status of raw cow's milk quality in the study area was far below from the milk quality standards. The titratable acidity of raw milk in rural was significantly $(\mathrm{p}<0.05)$ higher than the value of raw cow's milk from urban, peri-urban and cooperatives. This might be due to poor handling practice and unhygienic milking container, which means if improperly cleaned; some milk might be left in the container that may increase the acidity of raw milk.

Similarly, Asaminew and Eyassu reported higher acidity for milk samples collected from individual farmers $(0.23 \pm 0.01)$ and dairy cooperatives $(0.28 \pm 0.01 \%$ lactic acid $)$ in Bahir Dar Zuria district [17]. The titratable acidity milk obtained from vendors in Dire Dawa town was $0.216 \%$ [21].

Table1. Clot on boiling, alcohol test and titratable acidity of the raw milk in and around Bahir Dar city

\begin{tabular}{llllll}
\hline \multirow{2}{*}{ Factors } & $\mathrm{N}$ & \multicolumn{2}{c}{ Positive results (\%) } & $\begin{array}{c}\text { Titratable acidity } \\
\text { (LSM } \pm \text { SE) }\end{array}$ & Standard for titratable acidity \\
\cline { 3 - 4 } & & Clot on boiling test & Alcohol test & & \\
\hline Urban & 9 & - & 9.4 & $0.195 \pm 0.017^{\mathrm{a}}$ & $<0.14 \%$ \\
Peri-urban & 32 & 3.1 & 11.1 & $0.198 \pm 0.009^{\mathrm{a}}$ & \\
Rural & 34 & 29.4 & 38.2 & $0.235 \pm 0.0088^{\mathrm{b}}$ & \\
Cooperatives & 5 & - & 20 & $0.199 \pm 0.0231^{\mathrm{a}}$ & \\
\hline
\end{tabular}

LSM= Least Square Mean, N=Number of raw milk samples, Least square means followed by different superscript letters within a column are significantly different $(\mathrm{p}<0.05)$.

\subsection{Microbial counts of raw cow's milk}

\subsubsection{Coliform count}

Four types of bacteria were identified and counted (Figure2). The overall mean coliform count of raw cow's milk produced in the study area was $4.95 \log _{10} \mathrm{CFU} / \mathrm{ml}$. About $4.38 \pm 0.51,4.44 \pm 0.27$ and $5.57 \pm 0.26 \log _{10} \mathrm{CFU} / \mathrm{ml}$ coliform bacteria was found in urban, peri-urban and rural production systems, respectively (Table 2). This finding 
is higher than the acceptable level, the standard of European Union microbiological limit for coliform count in cow milk $\left(<2 \log _{10}\right.$ CFU/ml) [22].

The coliform count identified in rural production system $\left(5.57 \pm 0.26 \log _{10} \mathrm{CFU} / \mathrm{ml}\right)$ was significantly $(\mathrm{p}<0.05)$ higher than urban and peri-urban. The coliform count found in the study area was far above as compared to the result reported in Algeria (2.26 $\left.\log _{10} \mathrm{CFU} / \mathrm{ml}\right)$, Egypt (3.15 $\left.\log _{10} \mathrm{CFU} / \mathrm{ml}\right)$ and Slovenia $\left(2.1 \log _{10} \mathrm{CFU} / \mathrm{ml}\right)[23,24$, 25].

The result indicates that the milk has been contaminated with fecal materials, unclean udder and teats of cow's, inefficient cleaning of the milking containers and poor hygiene of the milking environment. Similarly, higher coliform count is commonly associated with manure or environmental contamination [26].

In line with this, $5 \log _{10} \mathrm{CFU} / \mathrm{ml} \mathrm{CC}$ was reported by Fanaye et al. [27] in the rural areas of Bahir Dar Zuria district. Similarly, the CC result of the milk samples collected from storage container at the farmer level in Hawassa was $4.93 \log _{10} \mathrm{CFU} / \mathrm{ml}$ [28]. In the contrary, higher $\left(9 \log _{10} \mathrm{CFU} / \mathrm{ml}\right)$ coliform counts were reported in Eastern Wollega [29]. According to Sisay Mesfine et al. [30], the overall mean of coliform count of raw milk was 1.24 $\log _{10} \mathrm{CFU} / \mathrm{ml}$ which is lower than the acceptable level. As the study conducted in Ezha district, $4.03 \log _{10} \mathrm{CFU} / \mathrm{ml}$ coliform counts were observed [31].

The analysis of variance showed that, there was a statistical significant difference $(p<0.05)$ in coliform count between the two milk sources. The coliform count of raw milk collected from cooperatives and individual dairy producers were 6.6 and $4.95 \log _{10} \mathrm{CFU} / \mathrm{ml}$, respectively. This result is higher than the finding of Asaminew and Eyassu [17] who found 4.41 and $4.49 \log _{10} \mathrm{CFU} / \mathrm{ml}$ coliform count in the milk collected from individual farmers and cooperatives, respectively. In the most part of the study area, raw milk was delivered to cooperatives through poor transportation without any cooling system, which might be the reason for the presence of highest coliform bacteria in cooperatives.

The present finding revealed that, the higher coliform count $\left(5.58 \log _{10} \mathrm{CFU} / \mathrm{ml}\right)$ was found in the milk sample obtained from unwashed udder. Whereas, only $3.34 \log _{10} \mathrm{CFU} / \mathrm{ml} \mathrm{CC}$ was observed in the raw milk samples from washed udder. There was high significance difference $(\mathrm{p}<0.01)$ in CC between the sample milked from washed and unwashed udder. This might be due to unwashed udder may have high amount of fecal materials and lead to contamination during milking (Table 2).

As indicated in the result, the use of traditional (gourd) milking container $\left(5.34 \log _{10} \mathrm{CFU} / \mathrm{ml}\right)$ contained significantly $(\mathrm{p}<0.05)$ higher coliform count than milked by plastic container $\left(4.45 \log _{10} \mathrm{CFU} / \mathrm{ml}\right)$ in the study area. This might be due to unsuitability of container for proper cleaning and allows the multiplication of bacteria on milk contact surfaces during the interval between milking. According to the result, $4.86 \pm 0.2$ and $5.48 \pm 0.48$ $\log _{10} \mathrm{CFU} / \mathrm{ml}$ coliform count were recorded from the raw milk samples milked by washed and unwashed hand, respectively. But there was no statistical difference between them. Even if, the coliform count in raw cow's milk is influenced by production systems, milk sources and types of milking container; however, hygiene of cow's udder was the potential sources of raw milk contamination by coliform bacteria (Table 2 ).

\subsubsection{Standard plate count}

The present finding indicated an overall mean standard plate count of raw milk in and around Bahir Dar was $7.11 \pm 0.13 \log _{10} \mathrm{CFU} / \mathrm{ml}$ (Table 2). This result is generally higher as compared to the internationally acceptable level of $\left(1 \times 10^{5} \mathrm{CFU} / \mathrm{ml}\right)$ bacteria per $\mathrm{ml}$ of raw milk [9]. Moreover, this value appears to be higher than the acceptable level of standard plate count $\left(5 \times 10^{4} \mathrm{CFU} / \mathrm{ml}\right)$ or $4.7 \log _{10} \mathrm{CFU} / \mathrm{ml}$ [32]. The SPC of raw cow's milk produced in the study area was far above the east African standard, since the minimum quality standard plate count value of Ethiopia is $6.3 \log _{10} \mathrm{CFU} / \mathrm{ml}$ or $2 \times 10^{6}$ [33]. On the other hand, relatively lower SPC $\left(6 \log _{10} \mathrm{CFU} / \mathrm{ml}\right) \mathrm{was}$ reported in and around Nairobi, Kenya [34].

Based on Kurwijila et al. [35], raw milk containing greater than $7 \log _{10} \mathrm{CFU} / \mathrm{ml}$ is categorized as poor grade. Therefore the milk found in and around Bahir Dar city was poor in quality. Since, it contains greater than $10,000,000 \mathrm{CFU} / \mathrm{ml} \mathrm{SPC}$. The current finding is also higher than the result of Bekele et al. [36] who reported the overall mean total bacterial count of cows' milk produced in Dangila town was $6.14 \pm 0.72 \log _{10} \mathrm{CFU} / \mathrm{ml}$. The study conducted by Melese and Tesfaye [37] also revealed that the overall mean count of total aerobic bacteria were 8.13 and $9.97 \log _{10} \mathrm{CFU} / \mathrm{ml}$ for milk samples collected from the milking bucket and storage containers, respectively.

However, the SPC obtained in this study is lower as compared other result which was $7.58 \log _{10} \mathrm{CFU} / \mathrm{ml}$ [17]. The standard plate count $\left(7.75 \pm 0.14 \log _{10} \mathrm{CFU} / \mathrm{ml}\right)$ analyzed from the raw milk samples from gourd (kell or 
Gereyra) milking container was significantly $(\mathrm{p}<0.05)$ higher than that of plastic milking container. Although, no statistically significance difference in SPC was observed by other factors.

\subsubsection{Yeast and mold count}

The overall mean yeast and mold count of raw cow's milk produced in the study area was $4.12 \pm 0.14 \log$ CFU $/ \mathrm{ml}$ which is greater than international quality standard $\left(0 \log _{10} \mathrm{CFU} / \mathrm{ml}\right)$ [38]. The result also higher than the finding of Bekele et al. [36] who reported that, the overall mean YMC of cows' milk produced in Dangla town was $0.68 \pm 0.41 \log _{10} \mathrm{CFU} / \mathrm{ml}$. Furthermore, higher yeast and mold count $\left(4.206 \pm 0.082 \log _{10} \mathrm{CFU} / \mathrm{ml}\right)$ was reported for milk samples in Shashemene town [39]. However, the current research finding is lower than the yeasts and mold count $\left(7.07 \pm 0.60 \log _{10} \mathrm{CFU} / \mathrm{ml}\right)$ found in Khartoum, North Sudan [40]. Contrary to the current study, about 2.3 $\log _{10} \mathrm{CFU} / \mathrm{ml}$ yeast and mold count was found in Slovenia [23].

Yeast and mold count in urban, peri urban and rural area were $2.51 \pm 0.34,4.02 \pm 0.18$ and $4.58 \pm 0.57$ $\log _{10} \mathrm{CFU} / \mathrm{ml}$, respectively. In the rural production system there was significantly $(\mathrm{p}<0.01)$ higher YMC compared to peri-urban and urban area. Moreover, the yeast and mold count obtained from gourd container was significantly $(\mathrm{p}<0.05)$ higher than milk samples collected from plastic milking container. Nevertheless, sources of milk, hygiene of milker's haven't statistically significant effect on yeast and mold count in raw cow's milk. Therefore, production system was the main determinant factor for greater yeast and mold count (Table 2).

\subsubsection{Staphylococcus aureus count}

As the current study showed, the overall mean staphylococcus aureus count of raw cow's milk produced and consumed in the study area was $3.36 \pm 0.11 \log _{10} \mathrm{CFU} / \mathrm{ml}$. This result is higher than the finding of Bogdanovieova et al. [41], the staphylococcus aureus count reported in Czech Republic was $2.7 \log _{10} \mathrm{CFU} / \mathrm{ml}$. Staphylococcus aureus count found in the milk samples obtained from rural area $\left(3.76 \pm 0.16 \log _{10} \mathrm{CFU} / \mathrm{ml}\right)$ was significantly $(\mathrm{p}<0.05)$ higher than both urban $\left(2.79 \pm 0.31 \log _{10} \mathrm{CFU} / \mathrm{ml}\right)$ and peri-urban production systems $(3.15 \pm 0.16$ $\log _{10} \mathrm{CFU} / \mathrm{ml}$ ) (Table 2). The reason for lowest count in the urban area might be due to better hygiene of milker and cows. Since, the high count of Staphylococcus aureus bacteria is associated with poor personal hygienic practices [42]. Although, Staphylococcus aureus count in this study is above the standard which is $0 \log _{10} \mathrm{CFU} / \mathrm{ml}$ [38].

In line with this finding, the overall mean count of $4.35 \pm 0.97 \log _{10} \mathrm{CFU} / \mathrm{ml}$ Staphylococcus aureus was also reported in Tigray region [43]. According to Betelihem and Shimels report, the raw milk samples collected from milking buckets were contaminated by staphylococcus aureus with average count of $7.56 \times 10^{2} \mathrm{CFU} / \mathrm{ml}$ [44]. In the present study, a staphylococcus aureus count $3.18 \pm 0.10$ and $4.43 \pm 0.26 \log _{10} \mathrm{CFU} / \mathrm{ml}$ was found in the milk sample milked by unwashed hand and washed hand, respectively. Highly significance difference $(\mathrm{p}<0.01)$ was observed between them and based on the result milker's hygienic status contribute for highest $S$. aureus count than other factors. This finding is consistent with Jorgensen et al. [45] report, S. aureus strains have occasionally been isolated from dairy cows and hands of milking person. Generally, the microbial count of standard plate count, coliform count, yeast and mold count and Staphylococcus aureus count of the raw cow's milk produced in and around Bahir Dar City were higher and far below the national and international milk quality standards (Table 2). 
Table2. Microbial counts of raw cow's milk $(\mathrm{LSM} \pm \mathrm{SE})$ in and around Bahir Dar city

\begin{tabular}{|c|c|c|c|c|c|}
\hline Factors & $\mathrm{N}$ & $\begin{array}{l}\mathrm{CC} \\
\left(\log _{10} \mathrm{CFU} / \mathrm{ml}\right)\end{array}$ & $\begin{array}{l}\text { SPC } \\
\left(\log _{10} \mathrm{CFU} / \mathrm{ml}\right)\end{array}$ & $\begin{array}{l}\text { YMC } \\
\left(\log _{10} \mathrm{CFU} / \mathrm{ml}\right)\end{array}$ & $\begin{array}{l}\text { St.au } \\
\left(\log _{10} \mathrm{CFU} / \mathrm{ml}\right)\end{array}$ \\
\hline \multicolumn{6}{|c|}{ Production systems } \\
\hline Urban & 9 & $4.38 \pm 0.51^{\mathrm{a}}$ & $6.77 \pm 0.4^{\mathrm{a}}$ & $2.51 \pm 0.34^{\mathrm{a}}$ & $2.79 \pm 0.31^{\mathrm{a}}$ \\
\hline Peri-urban & 32 & $4.44 \pm 0.27^{\mathrm{a}}$ & $7.08 \pm 0.21^{\mathrm{a}}$ & $4.02 \pm 0.18^{b}$ & $3.15 \pm 0.16^{\mathrm{a}}$ \\
\hline Rural & 34 & $5.57 \pm 0.26^{\mathrm{b}}$ & $7.23 \pm 0.2^{\mathrm{a}}$ & $4.58 \pm 0.57^{\mathrm{c}}$ & $3.76 \pm 0.16^{\mathrm{b}}$ \\
\hline Over all mean & 75 & $4.95 \pm 0.18$ & $7.11 \pm 0.13$ & $4.12 \pm 0.14$ & $3.36 \pm 0.11$ \\
\hline \multicolumn{6}{|l|}{ Sources of milk } \\
\hline $\begin{array}{l}\text { Individual dairy } \\
\text { Producer }\end{array}$ & 75 & $4.95 \pm 0.18^{\mathrm{a}}$ & $7.11 \pm 0.14^{\mathrm{a}}$ & $4.09 \pm 0.13^{\mathrm{a}}$ & $3.38 \pm 0.11^{\mathrm{a}}$ \\
\hline Cooperatives & 5 & $6.6 \pm 0.71^{b}$ & $7.49 \pm 0.57^{\mathrm{a}}$ & $4.2 \pm 0.53^{\mathrm{a}}$ & $4.1 \pm 0.43^{\mathrm{a}}$ \\
\hline \multicolumn{6}{|c|}{ Hygiene of cow's udder } \\
\hline Washed udder & 21 & $3.34 \pm 0.28^{\mathrm{a}}$ & $6.92 \pm 0.26^{\mathrm{a}}$ & $3.53 \pm 0.25^{\mathrm{a}}$ & $2.92 \pm 0.20^{\mathrm{a}}$ \\
\hline Unwashed udder & 54 & $5.58 \pm 0.17^{b}$ & $7.19 \pm 0.16^{\mathrm{a}}$ & $4.31 \pm 0.15^{b}$ & $3.53 \pm 0.12^{b}$ \\
\hline \multicolumn{6}{|c|}{ Milking container } \\
\hline Gourd & 40 & $5.34 \pm 0.24^{\mathrm{a}}$ & $7.75 \pm 0.14^{\mathrm{a}}$ & $4.38 \pm 0.18^{\mathrm{a}}$ & $3.50 \pm 0.15^{\mathrm{a}}$ \\
\hline Plastic & 26 & $4.45 \pm 0.27^{\mathrm{b}}$ & $6.29 \pm 0.16^{b}$ & $3.72 \pm 0.20^{\mathrm{b}}$ & $3.19 \pm 0.16^{\mathrm{a}}$ \\
\hline \multicolumn{6}{|c|}{$\begin{array}{l}\text { Milker's hygienic } \\
\text { status }\end{array}$} \\
\hline Washed hand & 64 & $4.86 \pm 0.2^{\mathrm{a}}$ & $7.07 \pm 0.15^{\mathrm{a}}$ & $3.99 \pm 0.15^{\mathrm{a}}$ & $3.18 \pm 0.10^{\mathrm{a}}$ \\
\hline Unwashed hand & 11 & $5.48 \pm 0.48^{\mathrm{a}}$ & $7.38 \pm 0.36^{\mathrm{a}}$ & $4.64 \pm 0.36^{\mathrm{a}}$ & $4.43 \pm 0.26^{b}$ \\
\hline
\end{tabular}

Least square means followed by different superscript letters within a column are significantly different $(\mathrm{P}<0.05)$. $\mathrm{CC}=$ Coliform count, $\mathrm{SPC}=$ Standard plate count, $\mathrm{YMC}=$ Yeast and mold count, $\mathrm{St} . \mathrm{au}=$ Staphylococcus aureus count, $\mathrm{LSM}=$ Least mean square, $\mathrm{SE}=$ Standard Error, $\mathrm{CFU}=$ colony forming unit and $\mathrm{N}=$ number of raw milk samples.

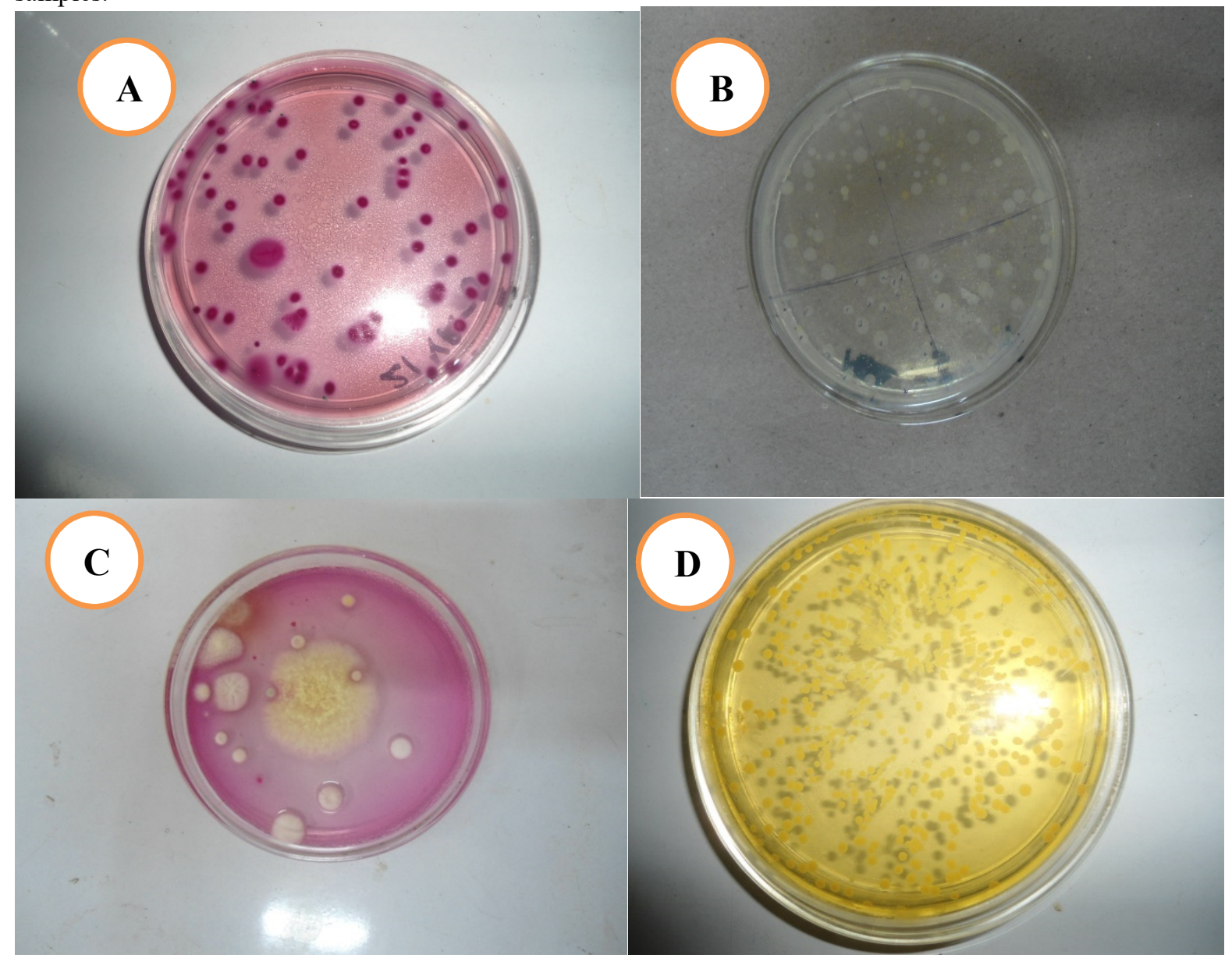

Figure2. Microbial counts found in the raw cow's milk

NB; $\mathrm{A}=$ Coliform, $\mathrm{B}=$ Standard plate, $\mathrm{C}=$ Yeast and mold, $\mathrm{D}=$ Staphylococcus aureus 


\section{Conclusions and Recommendations}

The highest proportion of positive results by clot on boiling and alcohol tests was observed in rural production system. The titratable acidity percentage of raw milk in the rural production system was greater followed by cooperatives. Moreover, the highest coliform, standard plate, yeast and mold and Staphylococcus aureus counts were found in the study area. This indicates that, the milk is contaminated with fecal materials, unclean udder of cows, inefficient cleaning of the milking containers and poor hygiene of the milking environment and milker's and these are critical points of contamination. The study result has shown, hygiene of udder of cow's, production system and hygienic status of milker's were the primary factors for highest coliform, yeast and mold and Staphylococcus aureus count, respectively. However, relatively good quality milk was obtained in urban production system. Generally, the quality of raw cow's milk produced in the study area was far below the acceptable level of most national and international milk quality standards which may have a great impact on public health, household economy and national growth. Hence, it needs immediate attention and actions to improve the existing situation in the area.

Based on these findings the following are recommended;

$>$ The coliform count, standard plate count and yeast and mold count in and around Bahir Dar city were far away from the international standards which may reduce the shelf life of milk and causing milk spoilage, therefore efficient milk cooling system is required at producer and milk collectors' level to reduce bacterial growth and milk loss.

$>$ Relatively better quality milk was obtained in the urban production system. Therefore management and hygienic practices implemented here shall be introduced and expanded to peri-urban and rural areas.

$>$ Since the staphylococcus aureus count in the study area was higher, there should be a health package and raw milk consumers should boil and pasteurize the raw milk before consumption.

$>$ Educational programs targeted at behavioral changes on use of water and hygiene is highly warranted.

\section{Conflicts of Interest}

The authors declare that they have no conflicts of interest.

\section{References}

[1] Fatine H., Abdelmoula E., Doha B. and Hinde H. 2012. Bacterial Quality of Informally Marketed Raw Milk in Kenitra City, Morocco. Pakistan J. Nutrition. 11: 662-669.

[2] Salman A. M. and Hamad M. 2011. Enumeration and identification of coliform bacteria from raw milk in Khartoum State, Sudan. Journal of Cell and Animal Biology. 5: 121-128.

[3] Merhawit R., Habtamu T., Berihun A. and Abrha B. 2014. Bacteriological quality assessment of milk in dairy farms, cafeterias and wholesalers in Adigrat, Tigray, Ethiopia. European Journal of Biological Sciences. 6: 88-94.

[4] Knight-Jones T. J. D., Hang'ombe M. B., Songe M. M., Sinkala Y., and Grace D. 2016. Microbial contamination and hygiene of fresh cow's milk produced by smallholders in western Zambia. International Journal of Environmental Research and Public Health. 13: 737.

[5] Grimaud P., Serunjogi M. L. and Grillet N. 2007. An evaluation of milk quality in Uganda: value chain assessment and recommendations. African Journal of Food Agriculture Nutrition and Development. 7: 1-16

[6] Zelalem Y. 2012. Microbial properties of Ethiopian marketed milk and milk products and associated critical points of contamination: An epidemiological perspective, epidemiology insights, Dr. Maria De Lourdes Ribeiro De Souza Da Cunha (Ed.), ISBN: 978-953-51-0565-7.

[7] BoARD. 2016. Bureau of Agriculture and Rural Development (BoARD) Amhara Region, Statistics section. Bahir Dar, Ethiopia.

[8] IDF 50 and ISO/DIS 707, 2008. Milk and milk products -Guidance on milk sampling. $3^{\text {rd }}$ ed.. Institute of Research, Technology and Science, Bhopal, India. International Journal of Standards, New Delhi. 1- 10pp.

[9] O’Connor CB. 1994. Rural Dairy Technology. ILRI Training Manual No.1. International Livestock Research Institute (ILRI), Addis Ababa, Ethiopia.

[10] Ombui J., Arimi S., Mcdermott J., Mbugua S., Githua A. and Muthoni J. 1995. Quality of raw milk collected and marketed by dairy cooperative societies in Kiambu Woreda, Kenya. Bulletin Animal, Health Production in Africa. 43: 277-284.

[11] Kurwijila R.L. 2006. Hygienic milk handling, processing and marketing: reference guide for training and certification of small-scale milk traders in Eastern Africa. ILRI (International Livestock Research Institute), Nairobi, Kenya.11pp.

[12] O’Connor CB. 1995. Rural Dairy Technology. ILRI Training Manual No.1. International Livestock Research Institute (ILRI), Addis Ababa,Ethiopia.

[13] APHA. 1992. Standard methods for the examination of water and wastewater. 18th edition, American public health association (APHA), American water works association (AWWA) and Water Pollution Control 
Federation (WPCF), Washington, D.C.

[14] APHA. 2001. Compendium of methods for the microbiological examination of foods. 4th ed., Washington, DC. Good-luxuriant. 50: 50-100.

[15] MMAF. 2012. Food safety and standards authority of Indian ministry of health and family welfare Government of India New Delhi. Manuals of Methods of Analysis of Food (MMAF), Lab. Manual. 14.

[16] Yousef AE. and Carlstrom C. 2003. Food microbiology; a laboratory manual. John Wiley and Sons, Inc., Hoboken, New Jersey, Canada.

[17] Asaminew T. and Eyassu S. 2011. Microbial quality of raw cow's milk collected from farmers and dairy cooperatives in Bahir Dar Zuria and Mecha district, Ethiopia. Agric Biol JN Am. 2: 29-33.

[18] Alganesh T. and Fekadu B. 2012. Traditional milk and milk products handling practices and raw milk quality in Eastern Wollega, Ethiopia. In: Laura Dean (ed.) LAP LAMBERT Academic Publishing. pp85.

[19] Monika S. and Poonam R. 2013. Microbiological and chemical analysis of raw, pasteurized and UHT milk during preservation in India. Department of applied chemistry, Bansal institute of research, technology and science, Bhopal, India. International Journal of Chemical Technology Resources. 5: 2804 - 2809.

[20] Popescu A. and Angel E. 2009. Analysis of milk quality and its importance for milk processors. Scientific Papers Animal Science and Biotechnologies. 42: 501-506.

[21] Teklemichael T., Ameha K. and Eyassu S. 2013. Quality and safety of cow milk produced and marketed in Dire Dawa town, Eastern Ethiopia.Int. J. Int Sci. Inn. Tech. Sec. B. 2: 01-05.

[22] European Union (EU). 2004. Regulation (EC) No 853/2004 of the European Parliament and of the Council of 29 April 2004 laying down specific hygiene rules for food of animal origin. J. Eur. Union. 139: $22-82$.

[23] Torkar K. G. and Teger S. G. 2008. The microbiological quality of raw milk after introducing the two day's milk collecting system. Acta agriculturae Slovenica. 92: 61-74.

[24] El-Leboudy A. A., Amer A. A. and El-Mohsen S. A. 2014. Detection of Some Pathogenic Organisms from Dairy Farm Milk. Alexandria Journal for Veterinary Sciences. 44.

[25] Titouche Y., Hakem A., Salmi D., Yabrir B., Chenouf N., Chergui A. and Houali K. 2016. Assessment of microbiological quality of raw milk produced at Tizi Ouzou area (Algeria). Asian J.Anim. Vet. Adv.11: 854860.

[26] EL-zubeir IEM. and Ahmed MI. 2007. The hygienic quality of raw milk produced by some dairy farms in Khartoum-Sudan. J. Microbiol. 2: 988-991.

[27] Fanaye S., Ashenafi M., Getachew T., Hailu M. 2015. Evaluation of the quality of cow milk consumed by children in and around Bahir Dar. Ethiopian Journal of Science and Technology. 8: 71-79.

[28] Haile W., Zelalem Y. and Yosef T. 2012. Hygienic practices and microbiological quality of raw milk produced under different farm size in Hawassa, southern Ethiopia. Agricultural Research and Reviews. 1: 132-142.

[29] Alganesh T. 2002. Traditional milk and milk products handling practices and raw milk quality in Eastern Wollega. M.Sc. Thesis, Alemaya University, Dire Dawa, Ethiopia.108pp.

[30] Sisay Mesfine, Teka Feyera, and Ousman Mohammed. 2015. Microbiological quality of raw cow's milk from four dairy farms in Dire Dawa city, eastern Ethiopia. World J. Dairy Food Sci. 10: 09-14.

[31] Abebe B., Zelalem Y. and Ajebu N. 2012. Hygienic and microbial quality of raw whole cow's milk produced in Ezha district of the Gurage zone, Southern Ethiopia. Journal of Agricultural Research. 1: 459-465.

[32] Altevogt B. M., Pankevich D. E., Shelton-Davenport M. K. and Kahn J. P. 2011. Institute of medicine (US) and national research council (US) committee on the use of chimpanzees in biomedical and behavioral research: Assessing the Necessity.

[33] ES. 2009. Unprocessed Whole/Raw Cow Milk Specification. 2nd Ed., 2009, Ethiopia.

[34] Wanjala GW., Mathooko FM., Kutima PM and Mathara JM. 2017. Microbiological quality and safety of raw and pasteurized milk marketed in and around Nairobi region. African Journal of Food, Agriculture, and Development. 17: 1.

[35] Kurwijila R.L., Hansen K.K., Macha I.E., Abdallah K., and Kadigi H.J.S. 1992. The Bacteriological Quality of Milk from Hand and Machine Milked Dairy Herds in Morongo, Tanzania, J. Afr. Livestock Res. 2: 59-67.

[36] Bekele A., Fekadu B. and Mitiku E. 2015. Handling, processing and marketing of cow milk in urban and peri urban area of Dangila Town, Western Amhara Region, Ethiopia. 3: 159-174.

[37] Melese A. and Tesfaye W. 2015. Bacteriological quality and safety of raw cow's milk in and around Jigjiga City of Somali Region, Eastern Ethiopia. Int. J Res Stud Biosci. 3: 48-55.

[38] Ministry of Agriculture and Rural Development and Ministry of Health, Social and Family Affairs, 2003. Magyar Közlöny. Official Journal of Hungary. 2: 59.

[39] Teshome G., Fekadu B. and Mitiku E. 2014. Handling practices and microbial quality of raw cow's milk produced and marketed in shashemene town, southern ethiopia. Int. J. Ag ric. Soil Sci. 2: 153-162.

[40] Rahamtalla S. A., Elsheikh N. A. and Abdalla, M. O. 2006. Microbiological quality of raw milk produced and distributed in Khartoum State, Sudan. ARPN Journal of Agricultural and Biological Science. Vol.11.

[41] Bogdanovieova K., Vyletelova-Klimesova M., Babak V., Kalhotka L., Kolackova I. and Karpiskova R. 2016. 
Microbiological Quality of Raw Milk in the Czech Republic. Czech Journal of Food Science. 34: 189-196.

[42] Yuen S. K., Yee C. F. and Yin. F. H. 2012. Microbiological quality and the impact of hygienic practices on the raw milk obtained from the small-scale dairy farmers in Sabah, Malaysia. International Journal of Agricultural and Food Science. 2: 55-59.

[43] Enquebaher T., Skeie S., Rudi K., Skjerdal T. and Narvhus J. A. 2015. Staphylococcus aureus and other Staphylococcus species in milk and milk products from Tigray region, Northern Ethiopia. African Journal of Food Science. 9: 567-576.

[44] Betelihem T. and Shimels T. 2017. Bacteriological milk quality: possible hygienic factors and the role of Staphylococcus aureus in raw bovine milk in and around Gondar, Ethiopia. International Journal of Food Contamination. 4: 1 .

[45] Jorgensen H.J., Mork T., and Rorvik L.M. 2005a. The occurrence of Staphylococcus aureus on a farm with small-scale production of raw milk cheese. Journal of Dairy Science. 88: 3810-3817.

\section{Budget sources}

This research was funded by Woldia University. Therefore I would like to thank Woldia University for their financial support.

\section{Data availability}

Currently, I'm not voluntary to share the data for privacy purpose and due to the need of my funding institution. 